\title{
ROADS AND ROADLESS AREAS IN CYPRUS: IMPLICATIONS FOR THE NATURA 2000 NETWORK
}

\author{
MARIA ZOMENI, IOANNIS. N. VOGIATZAKIS
}

School of Pure \& Applied Sciences, Open University of Cyprus, PO Box 12794, 2252 Nicosia, CYPRUS, email: maria.zomeni@ouc.ac.cy

Received: $15^{\text {th }}$ April 2014, Accepted: $31^{\text {th }}$ July 2014

\begin{abstract}
The road network in Cyprus has seen an $88 \%$ increase in the last 20 years. This expansion has not been followed by any kind of assessment on the effects of the network on nature conservation. This is the first island-wide quantitative assessment of the size, character (surface types), pervasiveness and distribution of the road system with particular reference to Natura 2000 network on the island. We mapped roadless areas (i.e. areas at least one km away from nearest road) for the whole island and examined the spatial distribution with respect to Natura 2000. We tested the relationship between overall road density and road density of different road categories within terrestrial Natura 2000 sites to four zones which were defined on the basis of landform, principal land use and ownership. We employed three indices i.e. effective mesh size, splitting and division to measure fragmentation caused by the road network within Natura 2000 and investigated the relationship between road density and the above fragmentation metrics. Mean road density in Cyprus is $2.3 \mathrm{~km} / \mathrm{km}^{2}$ which is comparable to road density values recorded in other Mediterranean countries such as France, Spain and Italy, which have much larger area and population. Roadless areas cover $4.5 \%$ of the island, and despite being scattered $80 \%$ is found within Natura 2000, which demonstrates the added value of the network for nature conservation. Road expansion has taken place throughout the island with the same intensity irrespectively of the zones examined. Fragmentation has been lower in sites on mountainous areas where sites are larger and under state ownership. Road density is negatively correlated $(\mathrm{r}=-0.383, \mathrm{p}=0.05)$ with effective mesh size and positively correlated with both landscape division $(\mathrm{r}=0.376, \mathrm{p}=0.05)$ and splitting index $(\mathrm{r}=0.376, \mathrm{p}=0.05)$. Results corroborate that spatial configuration is an important property of the road network in addition to traffic load, length and density. With the shift from site based conservation to landscape level there is a challenge for integrating technical, human and ecological requirements into infrastructure planning.
\end{abstract}

Key words: Fragmentation, Island, Mediterranean, Metrics, Road Density

\section{INTRODUCTION}

Roads facilitate flows of people across the landscape, including natural areas, and they act as drivers of land-use change and settlement establishment (Southworth et al., 2011). Roads are necessary for the economic activity in a region (Ahlström et al., 2011) and are essential to society. Although they serve as a link between detached areas, they break up nature into 
fragments in doing so. An overwhelming body of scientific literature is dedicated into describing the negative impacts that roads have on natural systems (Ament et al., 2008; Trombulak \& Frissell, 2000). Road construction interrupts horizontal ecological flows, alters landscape spatial pattern acting as barrier to animal movement and results in road mortality and habitat loss (van der Grift et al., 2013; Forman et al., 2003; Trombulak \& Frissell, 2000). In addition traffic noise and disturbance reduce habitat quality and hence alter the behaviour of animals which is manifested by road avoidance (Forman et al., 2003). Changes in the amount and quality of habitat related to roads and vehicles are considered more important than the direct effect of road kills by vehicle collisions (Bissonette, 2002). When roads act as barriers to movement, for many taxonomic groups, they reduce landscape connectivity and confine accessible habitat for species (Eigenbrod et al., 2008) thus resulting in higher mortality, smaller populations and lower population viability (Fahrig, 2003).

Among the aforementioned impacts, habitat fragmentation is considered as the most important of ecological effects of roads and associated traffic (e.g. Heilman et al., 2002; Spellerberg, 1998; Marsh \& Pearman, 1997). In addition to providing access to pristine areas road construction fragments native ecosystems into smaller patches of various sizes and shapes (Atkinson \& Cairns, 1992). At the landscape scale, roads cause fragmentation by removing habitat and creating high-contrast edges in previously continuous vegetation (Reed et al., 1996). Therefore roadless areas (i.e. areas without roads) and low-traffic areas (Selva et al., 2011) can contribute to the protection of the overall landscape connectivity in a given region, while maintaining a high level of core interior habitat (Strittholt \& DellaSala, 2001). However, while not dissected by roads, roadless areas may not be considered the relatively undisturbed and functioning ecosystems typically expected.

Understanding all aspects of ecological effects related to road systems, both positive and negative, helps to identify solutions for transportation policy and planning as well as effective conservation delivery. Mitigation and transportation planning solutions exist (Ford et al., 2011; van der Grift \& Pouwels, 2006; Jongman \& Pungetti, 2004), and work is under way for evaluating their effectiveness (Geneletti, 2006; Clevenger et al., 2001) but more pilot projects, and greater public understanding are needed (Forman, 2000). Likewise, more research is needed on long-term ecological effects of roads and how to monitor those effects (Beebee, 2013; van der Grift et al., 2013; Huijser et al., 2009; Girvetz \& Shilling, 2003). Even in Environmental Impact Assessments for road construction projects there is great variation on the level and quality of the biological material and ecological context provided (Graggaber \& Pistecky, 2012). There have been cases where roads were omitted in landscape analysis since they were "too problematic" to analyse (Heinz, 1999) or comprised a small amount of the total landscape (Luck \& Wu, 2002).

Although there is no legislation developed by the Council of Europe aimed at the avoidance of habitat fragmentation due to infrastructure, the issue has been incorporated in the Birds and Habitats Directives (CEC 1979; CEC 1992) and the Environmental Impact Assessment (EIA) Directive (85/337/EEC). The increase of protected areas in Europe following the implementation of Natura 2000 network saw an increase of roaded protected areas, which has not yet been followed by an in turn increase of research on their effects on biodiversity. Cyprus, an island considered as a biodiversity "hotspot" area (Myers et al., 2000), has transposed the Birds and Habitats Directives onto its national law and designated 40 Sites of Community Importance (SCIs) and 29 Special Protection Areas (SPAs) (some of which are overlapping) since it became an EU member in 2004. However, the road network in Cyprus is extensive and pervasive generating a highly dissected Natura 2000 network. Transport experienced a noteworthy growth over the last 20 years in Cyprus and has played a significant role in development, particularly in tourism and the export of goods and other 
services (ECORYS, 2006). Cypriots exhibit a high dependence on roads and vehicles, whilst the use of off-road four-wheel drive vehicles has made many remote natural areas more accessible for recreation. In order to deal with the adverse impacts of road construction and use, environmental protection must play a key role in transportation policy and decision making. Effort is made to comply with EU policies to address issues of air and water pollution, and climate change but it appears that impacts such as habitat and biodiversity loss have been considered poorly during road planning in Cyprus.

The aim of the paper is to assess the implications of road network expansion and roadless areas for the Natura 2000 network in Cyprus. The main objectives are to a) provide a quantitative assessment of the size, character (surface types), pervasiveness and distribution of the road system and b) quantify fragmentation caused by roads at site level from a geometric perspective (Jaeger, 2000), as a first step for integrating human-related processes into nature conservation efforts on the island.

\section{MATERIAL AND METHODS}

\section{Study area}

Cyprus is the third largest island in the Mediterranean Sea (after Sicily and Sardinia) and the largest island state with $797 \mathrm{~km}$ length of coastline, covering a total area of $9,250 \mathrm{~km}^{2}$ (Figure 1). Since 1974, following a turbulent history which resulted in an armed conflict Cyprus has been a divided island. In 2011 the Republic of Cyprus had a population density of $90 \mathrm{inh} / \mathrm{km}^{2}$ (Statistical Service, 2013), which is slightly lower to the population density estimated within the EU-27 in 2010 (116.7 persons per $\mathrm{km}^{2}$ which is more than 3.5 times as high as in the United States) (European Union, 2012). About half of the population lives in the four largest cities among which the capital Nicosia accommodates $39 \%$ of the population of Cyprus (Statistical Service, 2013).

The island is divided into three geomorphological zones, the Troodos mountains, the Pentadaktylos Range and the Mesaoria plain. Its climate is typically Mediterranean with hot, dry summers and mild winters, with rainfall occurring predominantly between November and April. Its insular character, the varied climate, geology and topography along with the long history of human activities dating back to at least $8200 \mathrm{AD}$, have shaped the landscape and created a wide variety of habitats where a large number of species flourish (Tsintides et al., 2002; Myers et al., 2000) (Table 1).

The study area includes the road system traversing the Republic of Cyprus and covers the entire Natura 2000 network (Figure 2). Natura 2000 in Cyprus comprises 61 designated sites (Table 1) and covers a total area of $1,760 \mathrm{~km}^{2}$. This, after considering dual designation status and site overlaps, translates to a terrestrial area of $1,630 \mathrm{~km}^{2}$ i.e. $28 \%$ of the Republic of Cyprus, since there are also 2 marine sites and marine areas included in some SCIs and SPAs. The network covers most of the geological formations present in Cyprus and a range of elevation from $0 \mathrm{~m}$ to $1,945 \mathrm{~m}$ above sea level. 


\section{Fig. 1: Cyprus map and the road network in Cyprus}

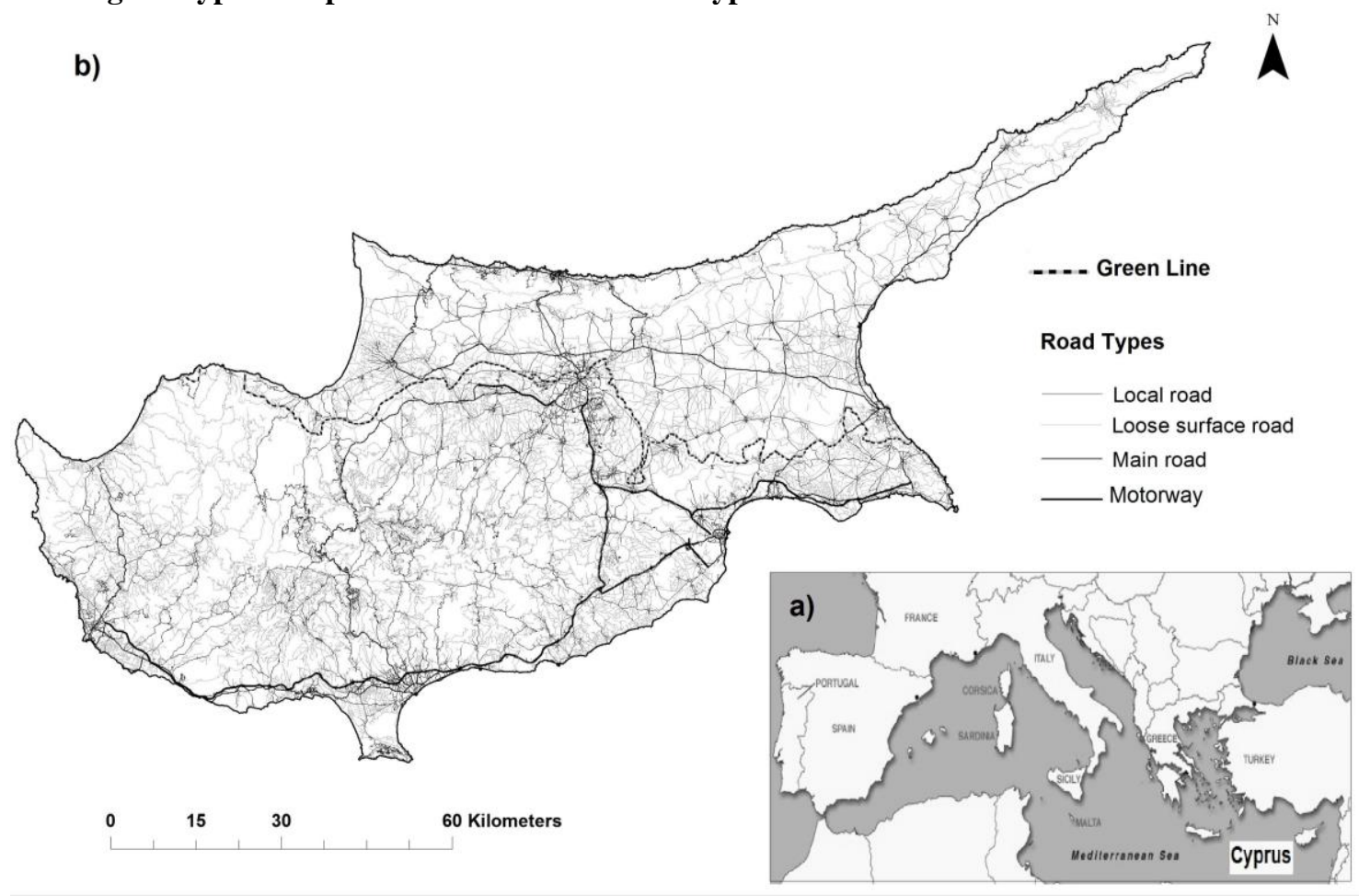

Table 1: Biodiversity and Natura 2000 sites in Cyprus

\begin{tabular}{|c|c|c|c|}
\hline \multicolumn{4}{|c|}{ Biodiversity } \\
\hline Flora & $\begin{array}{c}\text { c. } 1910 \\
\text { indigenous taxa }\end{array}$ & 143 endemics & \\
\hline Birds & c. 385 & 2 endemic, 4 subspecies & 53 permanent \\
\hline Mammals & c. 30 & $\begin{array}{c}2 \text { endemic (mice), } 2 \text { sub-endemic } \\
\text { (muflon \& hedgehog) }\end{array}$ & $\begin{array}{c}\text { Including } 18 \text { bats, } 3 \\
\text { dolphins, } 1 \text { seal }\end{array}$ \\
\hline Reptiles & 22 & 2 endemic & $\begin{array}{c}3 \text { turtles, } 11 \text { lizards, } 8 \\
\text { snakes }\end{array}$ \\
\hline Amphibians & 3 & 3 frogs & \\
\hline Fish & c. 250 & & \\
\hline Insects & $>5,000$ & & \\
\hline Natura 2000 & 32 SCIs & 21 SPAs & 8 SCI \& SPA \\
\hline $\begin{array}{l}\text { National Forest } \\
\text { Parks** }\end{array}$ & 10 & & \\
\hline $\begin{array}{l}\text { Nature } \\
\text { Reserves** }\end{array}$ & 7 & & \\
\hline $\begin{array}{l}\text { Habitat types } \\
\text { (Dir. 92/43/EEC) }\end{array}$ & 48 & 14 priority, 4 endemic & \\
\hline
\end{tabular}

* SCI: Site of Community Importance (Habitats Directive, 92/43/EEC), SPA: Special Protection Area (Birds Directive, 79/409/EEC)

** National designations 
Fig. 2: Roadless areas and the Natura 2000 network in Cyprus

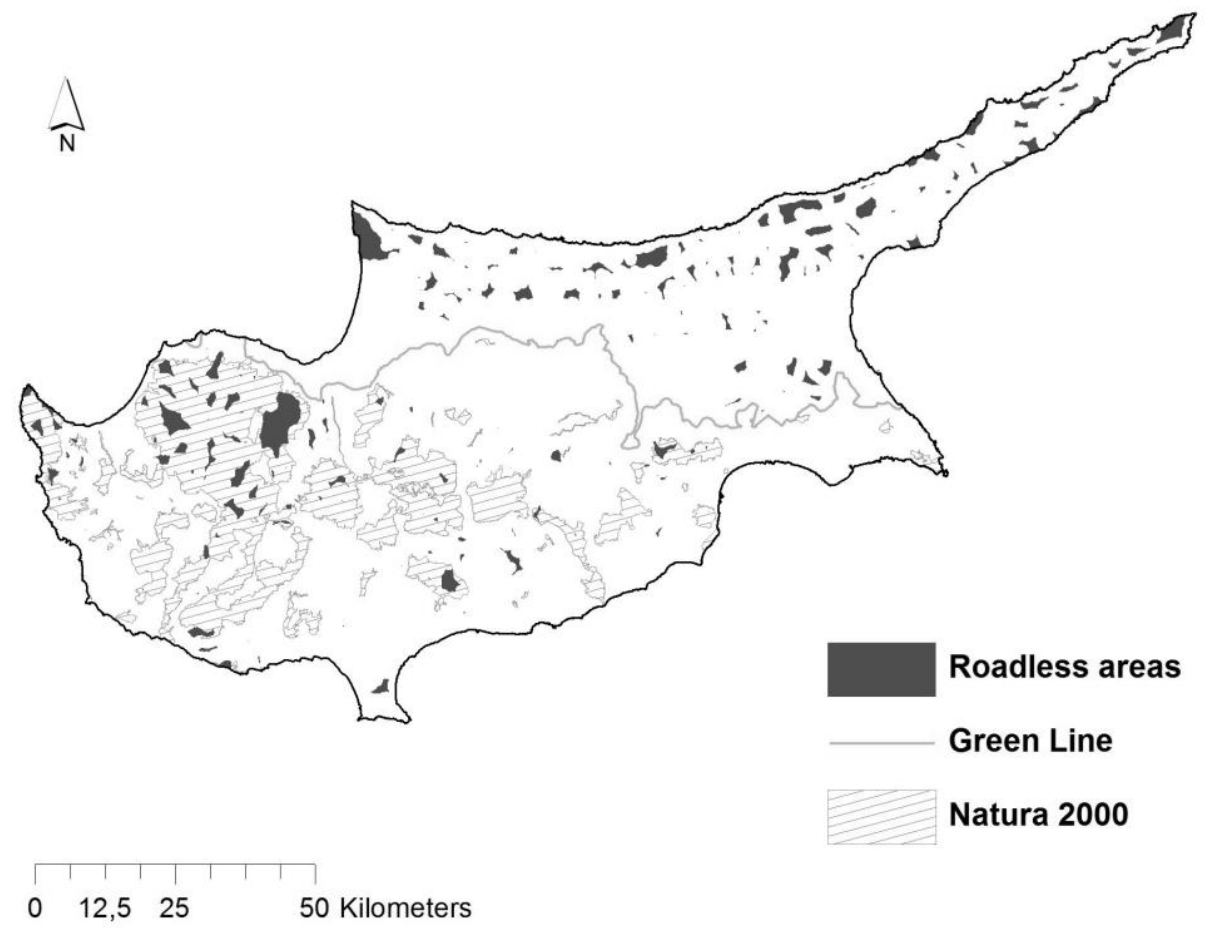

\section{Datasets and Metrics}

We used digital vector maps of the Natura 2000 network (http://www.eea.europa.eu /data-and-maps/data/natura-5\#tab-gis-data) (Figure 2) and the road network in Cyprus (Figure 1) within ArcGIS software (ESRI, 2012). Only terrestrial sites and the terrestrial part of sites including marine areas were studied i.e. 58 sites included in the Natura 2000 network of Cyprus. The map of roads used in this study (1:50000 scale: Department of Transport) included all existing road categories as well as forest roads, forest tracks, covering a total length of 13,267 km. We mapped roadless areas i.e. areas at least $1 \mathrm{~km}$ away from nearest road (BfN, 2008) for the whole island. The road network was overlaid on the CORINE land cover map (CLC 2006) (http://www.eea.europa.eu/data-and-maps/data/clc-2006-vector-data -version-3) for Cyprus and road density was estimated for different land cover/land use types. In addition, road density was calculated for each Natura 2000 site as the average total road length per unit area of landscape i.e. $\mathrm{km} / \mathrm{km}^{2}$, a useful measure of the amount of roads in an area and a measure related to many ecological processes (Forman \& Hersperger, 1996). Finally, three major fragmentation indices were calculated, namely landscape division, splitting index and effective mesh size as well as the number of patches for each Natura 2000 site using Vector-based Landscape Analysis Tools Extension for ArcGIS 10 (V-LATE 2.0 beta) (Lang \& Tiede, 2003). Landscape division, splitting index and effective mesh size are three quantitative measures that characterize landscape fragmentation in a geometric perspective (Jaeger, 2000). These measures have the particular advantage over other conventional measures of subdivision (e.g. mean patch size, patch density) in that they are insensitive to the omission or addition of very small patches. Twelve sites which did not comprise a contiguous area since their designation were omitted from the analysis. 


\section{Data analysis}

Natura 2000 sites were grouped according to four physiographic zones which reflect landform rather than absolute relief and are also associated with main land uses and ownership (Table 2). This grouping reflects both pressures on development/infrastructure and the degree of difficulty for road construction. These categories were coastal areas, i.e. $3 \mathrm{~km}$ from the coast, lowlands, hilly areas and mountain areas as derived from the Landscape Character Mapping for Cyprus (Warnock et al., 2008) (Table 2). Roads were grouped according to road surface type and the number of lanes as a proxy for traffic volume. As a result six road classes emerged i.e. motorways, main roads, local roads with one lane (local1), local roads with 2 lanes (local2), loose surface roads (including forest roads) with one lane (loose1) and loose surface roads with two lanes (loose2). Differences in the three fragmentation metrics and road density within these categories were tested for significance with a Kruskal Wallis test since the datasets were not normally distributed (Shapiro-Wilk test). Post hoc tests using pairwise comparison were used to determine differences between groups. We used Spearman rank correlation, after standardising the data in order to investigate the strength and direction of the relationship between road density and fragmentation metrics. Since the road density data did not follow the normal distribution either (Shapiro-Wilk test) we used Kruskal Wallis to test whether there is significant difference in the overall road density but also road density of the different road categories between the four zones. Main roads and motorways were not included in the analysis since they were found in very few sites. All tests were performed in SPPS version 22 (IBM Corp., 2013).

Table 2: Properties of the four physiographic zones used for statistical analysis

\begin{tabular}{|c|c|c|c|c|}
\hline Zones & Physiography & Principal Land use & $\begin{array}{c}\text { Principal } \\
\text { Ownership }\end{array}$ & Pressures \\
\hline 1 & Coastal areas & Urban, agriculture & Private & Tourism Development \\
\hline 2 & Lowland Areas & Agriculture & Private & Agricultural Intensification \\
\hline 3 & Hills & $\begin{array}{c}\text { Mixed } \\
\text { agrosilvopastoral }\end{array}$ & Private & Grazing \\
\hline 4 & Mountainous areas & $\begin{array}{c}\text { Forestry - Nature } \\
\text { Conservation }\end{array}$ & State & Recreation \\
\hline
\end{tabular}

\section{RESULTS}

A total length of $19,500 \mathrm{~km}$ of roads traverses the island. $68 \%$ of the road network i.e. $13,267 \mathrm{~km}$ of road is found in the area under Cyprus Government control $\left(5,759 \mathrm{~km}^{2}\right)$, mainly loose surface roads $8,608 \mathrm{~km}$ of paved roads (of which $257 \mathrm{~km}$ motorways/highways) (Statistical Service, 2012) constitute the primary road network within Cyprus and link the towns and villages, along with 1,400 km of gravel roads and 3,041 km of forest gravel roads. Overall, Cyprus exhibits a mean road density of $2.3 \mathrm{~km} / \mathrm{km}^{2}$.

Artificial surfaces have the highest mean road density of $5.43 \mathrm{~km} / \mathrm{km}^{2}$ followed by agricultural areas with a mean road density of $3.07 \mathrm{~km} / \mathrm{km}^{2}$. Maximum road densities exceeding $8 \mathrm{~km} / \mathrm{km}^{2}$ are found at permanently irrigated land and at complex cultivation patterns with scattered houses. Pastures appear less disturbed with $0.41 \mathrm{~km} / \mathrm{km}^{2}$ compared to the rest agricultural land cover types with mean road densities ranging between 2.5 and $3.8 \mathrm{~km} / \mathrm{km}^{2}$. Forests/semi-natural areas demonstrate mean road density of $1.74 \mathrm{~km} / \mathrm{km}^{2}$, among which broad-leaved forests and mixed forests hold the highest mean road densities 
(3.13 and 3.83 respectively). Mean road density in water bodies and wetlands is lower i.e. $1.06 \mathrm{~km} / \mathrm{km}^{2}$ and $0.52 \mathrm{~km} / \mathrm{km}^{2}$ respectively.

In total, 222 roadless areas were found scattered across the island covering only $4.5 \%$ of the area, $45 \%$ of which (186.5 $\mathrm{km}^{2}$ dispersed in 115 fragments) is found in the Cyprus Government control area. In their majority these roadless areas are very small patches less than $1 \mathrm{~km}^{2}$ whereas merely 6 such areas expand over more than $10 \mathrm{~km}^{2}$. These larger roadless areas are mainly found at high elevation, in contrast to the area not under Cyprus Government control where large roadless areas are found at low to medium elevation. By superimposing (CLC 2006) maps with roadless areas in Cyprus Republic we found that roadless areas are mainly concentrated in forests and semi-natural areas, especially coniferous forests, sclerophylous vegetation and transitional woodlands/shrubs. $83 \%$ of roadless areas $\left(155.16 \mathrm{~km}^{2}\right)$ is embedded in Natura 2000, however, they occur mainly as small patches less than $1 \mathrm{~km}^{2}$ (only 6 continuous roadless areas larger than $5 \mathrm{~km}^{2}$ ). By investigating the road network in nationally and internationally designated protected areas in Cyprus Republic we found that roadless areas are scarce in National Forest Parks and National Reserves even though they have been protected prior to their designation for protection at international level (Habitats \& Birds Directives).

Natura 2000 network is highly permeated by roads. A total road length of $2,718 \mathrm{~km}$ crosses Natura 2000 (20.5\% of total length of roads at national level) mainly loose surface roads $(2,325 \mathrm{~km})$. Road density averaged among sites reaches $1.94 \mathrm{~km} / \mathrm{km}^{2}$ which approaches the national road density $\left(2.3 \mathrm{~km} / \mathrm{km}^{2}\right)$. Road density in individual sites ranges between $0-$ $5.99 \mathrm{~km} / \mathrm{km}^{2}$, whilst after ignoring site boundaries and overlaps, the maximum road density recorded in a continuous area included in the Natura 2000 network skyrockets to $25 \mathrm{~km} / \mathrm{km}^{2}$. Only two very small terrestrial SCIs are not intersected by roads (Periochi Agiatis CY4000011 \& Periochi Drymou CY4000014). Mean road density outside the Natura 2000 network is estimated at $2.9 \mathrm{~km} / \mathrm{km}^{2}$.

Kruskal-Wallis test showed that there is no significant difference in overall road density among zones or in road density of different road classes between these zones (Table 3). However, effective mesh size varied significantly among the different zones (Table 4). Post hoc tests showed that this is due to high mesh size in zone 4 . There is no significant difference for landscape division and splitting index among zones. Road density is negatively correlated $(\mathrm{r}=-0.383, \mathrm{p}=0.05)$ with mesh size and positively correlated with both landscape division $(\mathrm{r}=0.376, \mathrm{p}=0.05)$ and splitting index $(\mathrm{r}=0.376, \mathrm{p}=0.05)$.

Table 3: Kruskal-Wallis test results $(p=0.005)$ for overall road density $(\mathrm{RD})$ among physiographic zones or road density of different road classes among these zones.

\begin{tabular}{|l|c|c|c|c|c|}
\hline & Overall RD & Local1 RD & Local2 RD & Loose1 RD & Loose2 RD \\
\hline Chi-Square & 2.650 & 6.048 & 4.993 & 0.754 & 3.079 \\
\hline df & 3 & 3 & 3 & 3 & 3 \\
\hline Asymp. Sig & 0.449 & 0.109 & 0.172 & 0.861 & 0.380 \\
\hline
\end{tabular}

Table 4: Kruskal-Wallis test results $(p=0.005)$ for the three fragmentation metrics among the physiographic zones.

\begin{tabular}{|l|c|c|c|}
\hline & Division & Splitting index & Effective Mesh Size \\
\hline Chi-Square & 5.376 & 5.317 & 18.839 \\
\hline df & 3 & 3 & 3 \\
\hline Asymp. Sig & 0.146 & 0.150 & 0.000 \\
\hline
\end{tabular}




\section{DISCUSSION}

Habitat loss and fragmentation, caused by agricultural intensification and urbanization, are the primary threats to biological diversity jeopardizing the stability and persistence of wildlife populations. Transport infrastructure has also been recognized as one of the most significant factors contributing towards the overall fragmentation effect and the associated decline of biodiversity in Europe (CEC, 2010) an important issue for European conservation policy (Iuell et al., 2002). In the absence of other transport means Cyprus is totally relying on the road network. Over the last 20 years there has been an $88 \%$ increase in the total length of public (including forest) roads in Cyprus (Statistical Service, 2012). The division of the island since 1974 resulted in doubling of major infrastructure including roads, with adverse environmental effects (Caramondani, 2002). This dense road network translates in a mean road density of $2.3 \mathrm{~km} / \mathrm{km}^{2}$ which is comparable to road density values recorded in other Mediterranean countries such as France, Spain and Italy (Figure 3). This is especially significant considering the small population of Cyprus compared to these other countries with Cyprus exhibiting the greatest length of roads per 1000 people i.e. almost $16 \mathrm{~km}$ of road corresponding to every 1000 persons.

The density of motorways in Cyprus $\left(28 \mathrm{~km} / 1000 \mathrm{~km}^{2}\right)$ is twice as high as the EU-25 average $\left(14 \mathrm{~km} / 1000 \mathrm{~km}^{2}\right)$ and the highest among the new member states (European Union, 2012). Similarly to other countries within the EU, in Cyprus the car is by far the most dominant mode of passenger transport, which is also evident by the increase of car ownership (with a total of 783,693 vehicles in 2011) (Statistical Service, 2012).

Road expansion in the Republic of Cyprus has taken place irrespectively of location and landform. This is also evidenced by the analysis of the four different zones examined as there is no difference in the overall road density or even between different road classes in the Natura 2000 sites.

Numerous comprehensive reviews analyze the direct and indirect ecological effects of transportation infrastructure on the environment and associated biodiversity (Saunders et al., 2002; Forman, 2000; Trombulak \& Friseell, 2000). The European Commission has adopted a strategy to halt biodiversity loss by 2020 , placing emphasis on maintaining the coherence of the Natura 2000 network, currently under increasing pressure from landscape fragmentation (CEC, 2010). To increase ecological coherence de-fragmentation measures have been proposed to assist species movement (van der Grift \& Pouwels, 2006) and ecological networks have been designed and applied (van der Sluis \& van Eupen, 2013; Jongman \& Pungetti, 2004). Within these networks roadless areas, depending on their size, can act as stepping stones, buffers or even core areas thus building resilience and coherence in the wider countryside (Lawton et al., 2012; McGarigal et al., 2001). Habitat patches in these undisturbed areas can function as refuge for many species forced to shift ranges due to climate change (Noss, 2001). In particular the roadless areas identified in Cyprus provide with stepping stones in some areas, as well as core areas within and outside the existing Natura 2000 network and should be therefore given more attention by conservationists and planners. 
Fig. 3: Road density relative to population in Cyprus and seven other Mediterranean countries (data source: http://data.worldbank.org/). Road density for Cyprus is shown twice (for the island as a whole and the Cyprus Republic).

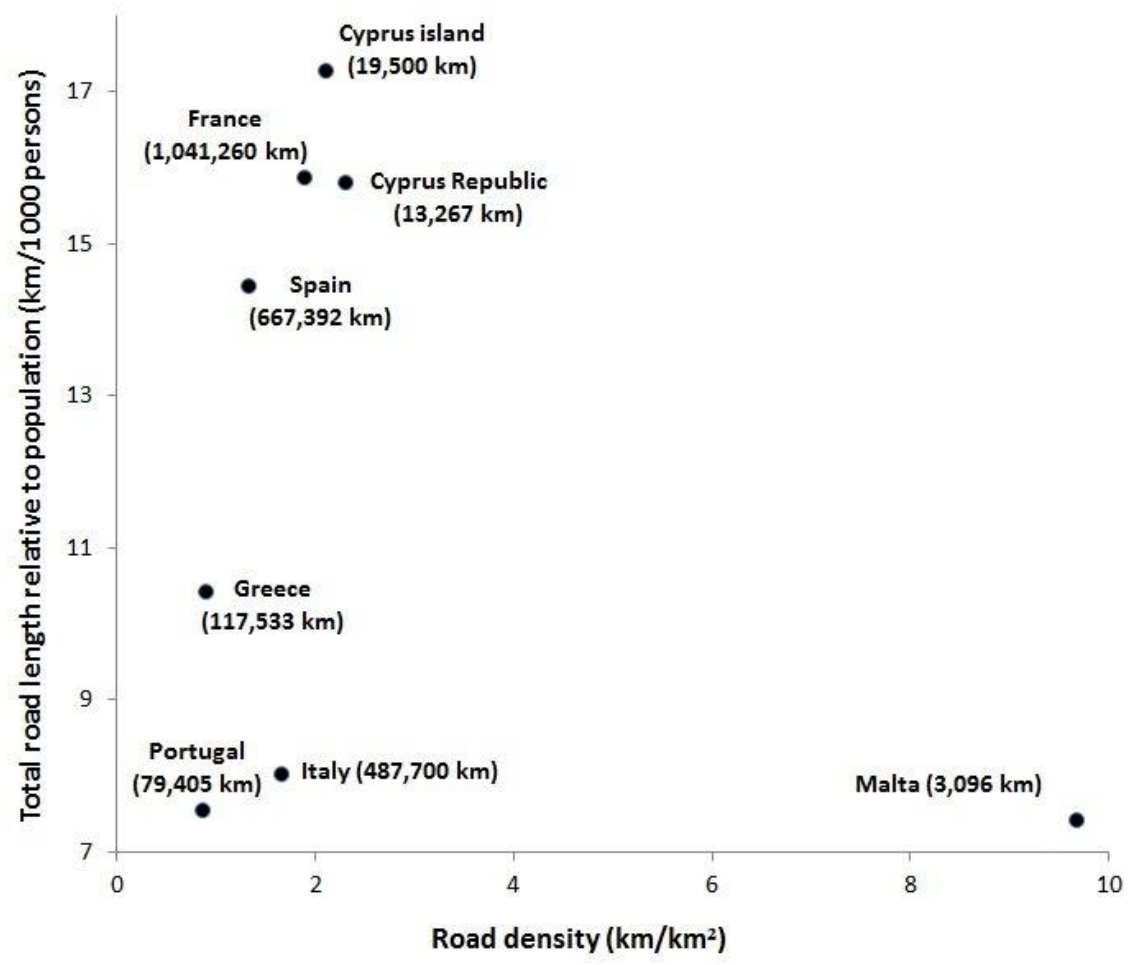

The average size of contiguous land units that are not cut through by major transport infrastructure ranges from about $20 \mathrm{~km}^{2}$ in Belgium to nearly $600 \mathrm{~km}^{2}$ in Finland, with an EU average of about $130 \mathrm{~km}^{2}$ (EEA, 2000). Despite their importance the few roadless areas left in Europe are mostly unprotected by law in contrast to the USA (Selva et al., 2011). Similarly, roadless areas in Cyprus are not considered as conservation targets in national laws or Conventions and European Directives in force. In Cyprus roadless areas (areas at least 1 $\mathrm{km}$ away from nearest road) are sparsely distributed covering only $4.5 \%$ of the island (i.e. $416 \mathrm{~km}^{2}$ ). In their majority they occur as very small patches less than $1 \mathrm{~km}^{2}$. Those larger than $10 \mathrm{~km}^{2}$ are mainly found at high elevation, concentrated in forests and semi-natural areas, in contrast to the area in the north part of the island where large roadless areas are found at low to medium elevation. This dissimilarity may be due to differences in natural conditions, political regimes, and social and economic development trends between the two areas. However, a very high percentage of roadless areas $\left(83 \%\right.$ or $\left.155.16 \mathrm{~km}^{2}\right)$ is embedded in designated Natura 2000 sites revealing the added value of the network on the island compared to other countries where additional designations might be necessary to protect roadless areas (e.g. Germany, see Selva et al., 2011). The two terrestrial SCIs which are not intersected by roads were located in rugged terrain. However, these two roadless sites comprise merely $0.25 \%$ of the terrestrial part of the Natura 2000 network in Cyprus which is much lower compared to the case of Greece with almost 3\% (Votsi et al., 2012). 
There is an increased interest in the effects of roads on landscape structure, habitat and species loss (Shinneman \& Baker, 2000; Spellerberg, 1998), particularly in protected areas (Garriga et al., 2012; Amen et al., 2008). Road density is a convenient measure of human presence on a landscape and may in some cases be appropriately used as a proxy for the suite of changes to landscape structure (Mladenoff et al., 1995). Although traffic volume and speed are within the parameters considered in road related studies (Eigenbrod et al., 2008), due to lack of data this was not possible in this study. However, the road categories used for the analysis can be considered as proxies for these parameters. In addition, the road map used was the best available for the whole island which did not include forest tracks or any information on the historical development of roads before and after the designation of Natura 2000 sites. Most of this dense road network was well in place by 2004 (Cyprus accession to the EU).

The high road density of Natura 2000 sites in Cyprus $\left(0-5.99 \mathrm{~km} / \mathrm{km}^{2}\right)$ reflects that of the country as a whole. Perhaps even more important is the fact that mean road density in 12 sites exceeds the national road density and for 8 of these it is even higher than mean road density outside the Natura 2000 network $\left(2.9 \mathrm{~km} / \mathrm{km}^{2}\right)$. In addition, after ignoring site boundaries and overlaps between sites (SCIs and SPAs), the maximum road density recorded in a continuous area included in the network reaches $25 \mathrm{~km} / \mathrm{km}^{2}$. These findings are a major concern suggesting that in Cyprus the road network has to be considered in future efforts to manage and monitor Natura 2000 sites.

Road density is a good surrogate for landscape impermeability for large carnivores (Carroll et al., 2003) and studies have shown strong inverse correlations between wildlife abundance and road density (Forman et al., 1997). Proposed acceptable figures for road density vary across landscapes. A road density of $0.6 \mathrm{~km} / \mathrm{km}^{2}$ would be the maximum for a naturally functioning landscape, containing sustainable populations of large predators (Forman \& Alexander, 1998) whereas in the Dutch agricultural landscapes values of $2.0-2.5 \mathrm{~km} / \mathrm{km}^{2}$ are considered the norm (Jaarsma \& Willems, 2002). Road density in Cyprus and in Natura 2000 clearly out range these values but the island does not host large predators. However, the high biodiversity of the island suggests that the maximum/acceptable value of road density clearly depends on the interaction among landscape structure and species habitat requirements; a relation that needs to be studied.

Along with the development of landscape ecology as a discipline came a plethora of indices including Ecological Scale Indices (Kupfer, 2012; Vos et al., 2001) which need to be interpreted from the species perspective in order to acquire ecological meaning. The three indices used in this study, although not directly related to species presence/abundance have been advocated as appropriate measures of the geometrical properties of an area (Jaeger, 2000) following fragmentation. In particular effective mesh size is 'area-proportionately additive', that is, it characterizes the subdivision of a landscape independently of its size. The road network obviously induces a high level of fragmentation on Natura 2000 and this was corroborated by this study i.e. the significant relationship between road density and effective mesh size. Mesh size varied significantly among zones with sites in mountain areas having higher on average mesh size. In other words areas of same road density do not necessarily have the same effective mesh size verifying that spatial configuration is an important property of the road network in addition to traffic load, length and density. This result reflects the fact that Natura 2000 sites in the mountain areas of Cyprus are in general larger and under state ownership and therefore are less fragmented by roads compared to other zones on the island. Although there is a high road density even in the mountain areas, not all road segments dissect the Natura 2000 sites and as a result they do not contribute to fragmentation at the site level. In these areas road infrastructure has been mainly the result of planning for 
increased access for recreation but also for forest management through the construction of forest roads.

Apart from direct negative impacts of roads on Cyprus biodiversity such as the use of invasive species for landscaping areas during road construction there is also the ecological effect of road avoidance caused by traffic disturbance or 'virtual footprint' which is assumed to be much greater than that of roadkills (Forman et al., 2003). Recent research that included 38 Natura 2000 sites in Cyprus showed that birds are adversely affected by the density of roads, especially in small areas, due to both direct and indirect effects such as road mortality, noise and habitat degradation (Mammides, 2012). This is extremely important considering the rich avian diversity of the island and the fact that it is a wintering site for numerous migrating birds.

\section{Policy and Planning Implications}

The design of motorways in Cyprus is considered to serve against habitat fragmentation through measures such as the establishment of underpasses every $2 \mathrm{~km}$ of motorway on average and in some cases every $600 \mathrm{~m}$ (usually $9 \mathrm{~m}$ wide and $5.3 \mathrm{~m}$ high) for the access of vehicles, but also facilitating animal crossings and the provision of drainage structures (usually large $2 \times 2 \mathrm{~m}$ ) which due to the Cyprus arid climate can also serve for fauna crossing (Caramondani, 2002). Road kills on the island include usually dogs and cats but also other small mammals (e.g. hedgehogs, hares and reptiles). Motorway fencing in order to reduce road accidents caused by animal crossings is adding to their barrier effect. Planning of secondary rural road network has not provided against habitat fragmentation and no real practical measures have been taken. The preparation of thorough Environmental Impact Assessments on the effects of proposed infrastructure on biodiversity is an important step to improve the situation. However, this is still lagging behind despite the fact that the country has to comply with EU legislation.

Despite the general awareness of the effects of current and future infrastructure on habitat fragmentation and the urgent request for planning tools, empirical data on the actual impact of infrastructure on wildlife is still scarce (Treweek et al., 1993). With respect to protected areas and road network in the EU more work is necessary particularly for the newly designated Natura 2000 sites to understand further the impacts of road construction to ecological processes and mitigate these impacts as necessary. Mitigation measures for wildlife movements are common worldwide if avoidance of road construction is not feasible (van der Grift \& Pouwels, 2006; Iuell et al., 2003). Several countries have adopted an ecological compensation principle, substitution of ecological functions or qualities that are impaired by development, in order to counterbalance its adverse impacts on nature (Villaroya $\&$ Puig, 2013). Other planning suggestions include the concentration of traffic on primary roads in rural landscapes, minimization of the conversion of secondary roads from light to medium traffic usage, linearization of road system and avoidance of multiple small roads (Forman, 2000). Forman \& Deblinger (2000) suggest a separation between busy roads and protected areas and a better design of future transportation systems across landscapes that can provide for ecological flows and biological diversity. However, further improvement is needed in the design and implementation of mitigation measures, as well as the quality control of existing measures through follow-up studies.

Kharecha (1997) advocates road maintenance over road building as the best strategy to accomplish the goals of the transportation system without increasing environmental costs. Since Cyprus has constructed a dense road network, there is almost no need for new roads, so it is the policy of the government to put its emphasis more on road network maintenance and less on new infrastructure projects (ECORYS, 2006). One of the long term targets of the 
National Transport Strategy and Planning is the upgrading of the main transport infrastructure (airports, ports and roads) of Cyprus so that it will be effectively linked with the Trans-European Networks (European Union, 2004). It also aims at safeguarding the free flow of passengers and goods and discouraging the excessive use of private vehicles while encouraging the use of mass transport systems. Transport has been identified as a major contributor to environmental pollution and since 2004 the Ministry of Communications and Works has been enforcing measures for the encouragement of the sustainable use of energy in the transport sector.

The above measures however should be incorporated into a wider planning effort as dictated by the principles of landscape ecology. Infrastructure planning must involve a landscape wide, holistic approach that integrates technical, human and ecological requirements. With the shift from site based conservation to landscape level one of the challenges is to use the information on linear infrastructure configuration into management and monitoring of Natura 2000 sites in Europe. This may include using the spatial configuration of roads to monitor changes in fragmentation, even from a purely geometric perspective. The information can assist with spatial targeting and decision making where a choice for resource allocation has to be made between sites of similar ecological value but different levels of fragmentation. This is one of the many examples where effectively integrating human-related processes into ecology must remain an aim and challenge for ecologists (Wu \& Hobbs, 2002) and where a "holistic landscape ecology" perspective, a systems view that links natural and human systems, as advocated by Naveh (2007) is necessary.

\section{REFERENCES}

Ahlström, A., Pilesjö, P., \& Lindberg, J. (2011). Improved accessibility modeling and its relation to poverty - A case study in Southern Sri Lanka, Habitat International 35, 316-326

Ament, R., Clevenger, A. P., Yu, O. \& Hardy, A., (2008). An assessment of road impacts on Wildlife populations in U.S. National Parks. Environmental Management (42), 480-496.

Atkinson, R. B. \& Cairns, Jr., (1992). Ecological risks of highways. In J. Cairns, Jr., B. R. Niederlehner \& D. R. Orvos (Eds.), Predicting ecosystem risk (pp. 237-262). Princecton Scientific Publishing, Princeton, New Jersey.

Beebee, T. J., (2013). Effects of road mortality and mitigation measures on amphibian populations. Conservation Biology, 27(4), 657-668.

BfN (Bundesamt für Naturschutz, Federal Agency for Nature Conservation), (2008). Nature Data 2008. BfN, Bonn.

Bissonette, J. A., (2002.) Scaling roads and Wildlife: the Cinderella Principle. Zeitschrift für Jagdwissenschaft (2000 supplement) 48: 208-214.

Caramondani, A., (2002). Habitat Fragmentation due to Transportation Infrastructure. National State of the Art Report Cyprus. Management Committee -COST 341/8 - CY.

Carroll, C., Phillips, M. K., Schumaker, N. H. \& Smith, D. W., (2003). Impacts of Landscape Change on Wolf Restoration Success: Planning a Reintroduction Program Based on Static and Dynamic Spatial Models. Conservation Biology (17): 536-548.

Clevenger, A. P., Chruszcz, B., \& Gunson, K. E. (2001). Highway mitigation fencing reduces wildlife-vehicle collisions. Wildlife Society Bulletin, 646-653.

CEC (Commission of the European Communities) (1979). Council directive 79/409/EEC on 
the conservation of wild birds. Official Journal of European Communitites No. L103/25.

CEC (Commission of the European Communities) (1992). Council Directive 92/43/EEC on the conservation of natural habitats and of wild fauna and flora. Official Journal of European Communities No. L206/7.

CEC (Commission of the European Communities) (2010). Communication from the Commission to the European Parliament, the Council, the European Economic and Social Committee and the Committee of the Regions: options for an EU vision and target for biodiversity beyond 2010. Retrieved June 30, 2011, from: http://ec.europa.eu/environment/ nature/biodiversity/policy/pdf/communication_2010_0004.pdf

ECORYS, (2006). Study on Strategic Evaluation on Transport Investment Priorities under Structural and Cohesion funds for the Programming Period 2007-2013. No 2005.CE.16.0.AT.014. Country Report Cyprus, Final. Rotterdam, European Commission.

EEA, (2000). Are we moving in the right direction? Indicators on transport and environment integration in the EU. TERM 2000. Environmental issues series no 12. Copenhagen. ISBN 92-9167-206-8. pp. 136.

Eigenbrod, F., Hecnar, S. J, Fahrig, L., (2008). The relative effects of road traffic and forest cover on anuran populations. Biological Conservation (141) 35-46.

ESRI, (2012). ArcMap, version 10.1. Environmental Systems Research Institute, Redlands, CA.

European Union, (2004). Decision No 884/2004/EC of the European Parliament and of the Council of 29 April 2004 amending Decision No 1692/EC on Community guidelines for the development of the trans-European transport network. Official Journal of the European Union L 201 (Corrigendum to L 167), 1-55.

European Union, (2012). Europe in figures - Eurostat yearbook 2012. Luxembourg: Publications Office of the European Union.

Fahrig, L., (2003). Effects of Habitat Fragmentation on Biodiversity. Annual Review of Ecology, Evolution and Systematics (34) 487-515.

Ford, A. T., Clevenger, A. P., Huijser, M. P., \& Dibb, A., (2011). Planning and prioritization strategies for phased highway mitigation using wildlife-vehicle collision data. Wildlife Biology, 17(3), 253-265.

Forman, R. T. T., (2000). Estimate of the area affected ecologically by the road system in the United States. Conservation Biology (14) 31-35.

Forman, R. T. T. \& Alexander, L. E., (1998). Roads and their major ecological effects. Annual Review of Ecology and Systematics (29) 207-231.

Forman, R. T. T., Sperling, D., Bissonette, J. A., Clevenger, A. P., Cutshall, C. D., Dale, V. H., Fahrig, L., France, R., Goldman, C. R., Heanue, K., Jones, J. A., Swanson, F. J., Turrentine, T. \& Winter, T. C., (2003). Road Ecology: Science and Solutions. Island Press, Washington, D. C. 481pp.

Forman, R. T. T. \& Deblinger, R. D., (2000). The ecological road-effect zone of a Massachusetts (USA) suburban highway. Conservation Biology (14) 36-46.

Forman, R. T. T., Friedman, D. S., Fitzhenery, D., Marten, J. D., Chen, A. S. \& Alexander, L. E., (1997). Ecological effects of roads: toward three summary indices and an overview for the North America. In K. Canters (Ed.), Habitat fragmentation and infrastructure (pp. 40-54). Ministry of Transport, Public Works and Water Management, Delft, The Netherlands. 
Forman, R. T. T. \& Hersperger, A. M., (1996). Road ecology and road density in different landscapes, with international planning and mitigation solutions. In G. L. Evink, P. Garret, D. Zeigler \& J. Berry, (Eds.), Trends in addressing transportation related wildlife mortality (pp. 1-22). Publication FL-ER-58-96.

Garriga, N., Santos, X., Montori, A., Richter-Boix, A., Franch, M., \& Llorente, G. A., (2012). Are protected areas truly protected? The impact of road traffic on vertebrate fauna. Biodiversity and Conservation, 21(11), 2761-2774.

Geneletti, D., (2006). Some common shortcomings in the treatment of impacts of linear infrastructures on natural habitat. Environmental Impact Assessment Review, 26(3), 257-267. Girvetz, E., \& Shilling, F., (2003). Decision support for road system analysis and modification on the Tahoe National Forest. Environmental Management, 32(2), 218-233.

Graggaber, M. \& Pistecky, W., (2012). The implementation of the Environmental Impact Assessment on the basis of precise examples. EU IMPEL, Nicosia, 2012.

Heilman, G. E., Strittholt, J. R., Slosser, N. C. \& Delassala, D. A., (2002). Forest fragmentation of the conterminous United States: assessing forest intactness through road density and spatial characteristics. Bioscience (52) 411-422.

Heinz, H. J., (1999). Designing a Report on the State of the Nation's Ecosystems: Selected Measurements for Croplands, Forests and Coasts \& Oceans. Washington (DC): H. John Heinz III Center

Huijser, M. P., Duffield, J. W., Clevenger, A. P., Ament, R. J., \& McGowen, P. T., (2009). Cost-benefit analyses of mitigation measures aimed at reducing collisions with large ungulates in the United States and Canada; a decision support tool. Ecology and Society, 14(2), 15.

IBM Corp, (2013). IBM SPSS Statistics for Windows, Version 22.0. Armonk, NY: IBM Corp.

Iuell, B., Bekker, G.J., Cuperus, R., Dufek, J., Fry, G., Hicks, C., Hlavácc, V., Keller, V., B., Rosell, C., Sangwine, T., Tørsløv, N., Wandall, B. le Maire, (Eds.) (2003). Wildlife and Traffic, A European Handbook for Identifying Conflicts and Designing Solutions. .

Jaarsma, C. F. \& Willems, G. P. A., (2002). Reducing habitat fragmentation by minor rural roads through traffic calming. Landscape and Urban Planning (58) 125-135.

Jaeger, J. A. G., (2000). Landscape division, splitting index and effective mesh size: new measures of landscape fragmentation. Landscape Ecology (15) 115-130.

Jongman, R. H. G. \& Pungetti, G., (2004). Ecological Networks and Greenways. Concept, Design, Implementation. Cambridge University Press.

Kharecha, P., (1997). Energy evaluation of the effects of human activities on Luquillo Experimental Forest, Puerto Rico. Thesis. Department of Environmental Engineering Sciences, University of Florida, Gainesville, FL.

Kupfer, J. A., (2012). Landscape ecology and biogeography: Rethinking landscape metrics in a post-FRAGSTATS landscape. Progress in Physical Geography (36) 400-420.

Lang, S. \& Tiede, D., (2003). vLATE Extension für ArcGIS - vektorbasiertes Tool zur quantitativen Landschaftsstrukturanalyse, ESRI Anwenderkonferenz 2003 Innsbruck. [CDROM].

Lawton, J.H., Brotherton, P.N.M., Brown, V.K., Elphick, C., Fitter, A.H., Forshaw, J., Haddow, R.W., Hilborne, S., Leafe, R.N., Mace, G.M., Southgate, M.P., Sutherland, W.A., Tew, T.E., Varley, J., \& Wynne, G.R., (2010) Making Space for Nature: a review of England's wildlife sites and ecological network. Report to Defra. 
Luck, M. \& Wu, J., (2002). A gradient analysis of urban landscape pattern: a case study from the Phoenix metropolitan region, Arizona, USA. Landscape Ecology (17) 327-339.

Mammides, C., (2012). Using statistical modelling to link disparate sources of available information to study factors that influence bird distributions. Unpublished doctoral dissertation. Imperial College: London, UK.

Marsh, D. M. \& Pearman, P. B., (1997). Effects of habitat fragmentation on the abundance of two species of Leptodactylid frogs in an Andean montane forest. Conservation Biology (11) $1323-1328$.

McGarigal, K., Romme, W. H., Crist, M. \& Roworth, E., (2001). Cumulative effects of roads and logging on landscape structure in the San Juan Mountains, Colorado (USA). Landscape Ecology (16) 327-349.

Mladenoff, D. J., Sickley, T. A., Haight, R. G. \& Wydeven, A. P., (1995). A regional landscape analysis and prediction of favorable gray wolf habitat in the northern Great Lakes Region. Conservation Biology (9) 279-294.

Myers, N., Mittermeier, R. A., Mittermeier, C. G., Fonseca, G. A. B. \& Kent, J., (2000). Biodiversity Hotspots for conservation priorities. Nature (43) 853-858.

Naveh, Z., (2007). Transdisciplinary Challenges in Landscape Ecology and Restoration Ecology - An Anthology. Springer Landscape Series.

Noss, R. F., (2001). Beyond Kyoto: forest management in a time of rapid climate change. Conservation Biology, 15(3), 578-590.

Reed, R. A., Johnson-Barnard, J. \& Baker, W. L., (1996). Contribution of roads to forest fragmentation in the Rocky Mountains. Conservation Biology (10) 1098-1106.

Saunders, S. C., Mislivets, M. R., Chen, J., \& Cleland, D. T., (2002). Effects of roads on landscape structure within nested ecological units of the Northern Great Lakes Region, USA. Biological Conservation, 103(2), 209-225.

Selva, N., Kreft, S., Kati, V., Schluck, M., Jonsson, B. G., Mihok, B., Okarma, H. \& Ibisch, P. L., (2011). Roadless and low-traffic areas as conservation targets in Europe. Environmental Management (48) 865-877. doi: 10.1007/s00267-011-9751-z

Shinneman, D. J. \& Baker, W. L., (2000). Impact of logging and roads on a Black Hills ponderosa pine forest landscape. In R. L. Knight, F. W. Smith, S. W. Buskirk, W. H. Romme \& W. L. Baker (Eds.), Forest Fragmentation in the Southern Rocky Mountains (pp. 311335.), University Press of Colorado, Boulder, CO.

Spellerberg, I. F., (1998). Ecological effects of roads and traffic: a literature review. Global Ecology and Biogeography Letters (7) 317-333.

Statistical Service, (2012). Transport Statistics 2012. Republic of Cyprus. Series II, Report No. 28.

Statistical Service, (2013). Population census 2011. Republic of Cyprus, Retrieved July 30, 2013,from: http://www.cystat.gov.cy/mof/cystat/statistics.nsf/populationcondition_22main_ en/populationcondition_22main_en?OpenForm\&sub=2\&sel=2.

Strittholt, J. R. \& Dellasala, D. A., (2001). Importance of roadless areas in biodiversity conservation in forested ecosystem: case study of the Klamath-Siskiyou ecoregion of the United States. Conservation Biology (15) 1742-1754.

Southworth J, Marsik M, Qiu Y, Perz S, Cumming G, Stevens F, Rocha K, Duchelle A, \& Barnes G., (2011). Roads as Drivers of Change: Trajectories across the Tri-National Frontier in MAP, the Southwestern Amazon. Remote Sensing 3(5):1047-1066. 
Treweek, J. R., Thompson, S., Veitch, N. \& Japp, C., (1993). Ecological assessment of proposed road developments: a review of environmental statements. Journal of Environmental Planning \& Management (36) 295-307.

Trombulak, S. C. \& Frissell, C. A., (2000). Review of ecological effects of roads on terrestrial and aquatic communities. Conservation Biology (14) 18-30.

Tsintides, T. C., Hadjikyriakou, G. N. \& Christodoulou, C. S., (2002). Trees And Shrubs In Cyprus. Anastasios G Leventis Foundation and Cyprus Forest Association, Lefkosia, 442 pp van der Grift, E. A., van der Ree, R., Fahrig, L., Findlay, S., Houlahan, J., Jaeger, J. A. G., Klar, N., Madriñan, L.F., \&. Olson, L., (2013). Evaluating the effectiveness of road mitigation measures. Biodiversity and Conservation, 22(2), 425-448. doi: 10.1007/s10531 $-012-0421-0$

van der Grift, E., \& Pouwels, R. (2006). Restoring habitat connectivity across transport corridors: Identifying high-priority locations for de-fragmentation with the use of an expert-based model. Ecology of Transportation: Managing Mobility for the Environment, 10, 205-231.

van der Sluis, T., \& van Eupen, M., (2013). Lifelines for Ramat Hanadiv - analysis of necessity of ecological corridors (with Hebrew summary). Wageningen: Alterra.

Villarroya, A., \& Puig, J., (2013). A proposal to improve ecological compensation practice in road and railway projects in Spain. Environmental Impact Assessment Review, 42, 87-94.

Vos, C. C., Verboom, J., Opdam, P. F. M., \& Ter Braak, C. J. F., (2001). Toward ecologically scaled landscape indices. American Naturalist, 157(1), 24-41..

Votsi, N-E., Mazaris, A. D, Kallimanis, A. S., Zomeni, M. S., Vogiatzakis, I. N., Sgardelis, S. P. \& Pantis, J. D., (2012). Road effects on habitat richness of the Greek Natura 2000 network. Nature Conservation (1) 53-71. doi: 10.3897/natureconservation.1.2086

Warnock, S., Griffiths, G., \& Vogiatzakis, I., (2008). Cyprus Landscape Mapping Project, Final Report, December 2008. UK: University of Reading.

Wu, J. \& Hobbs, R., (2002). Key issues and research priorities in landscape ecology: an idiosyncratic synthesis. Landscape Ecology (17) 355-365. 